\title{
Mellon Institute of Industrial Research
}

HE new building of the Mellon Institute of
Industrial Research in the University of Pitts-
burgh was dedicated on May 6, addresses being given
by three Nobel laureates, Dr. Irving Langmuir, Dr.
H. C. Urey, and Dr. W. P. Murphy. On the following
day, a symposium on recent progress in science was
held, to which Dr. G. O. Curme, Dr. F. B. Jewett,
An important development, with which Duncan would have been in full sympathy, was the establishment in 1924 of the Department of Research in Pure Chemistry.

Details of the scheme of industrial fellowships having been given from time to time in NATURE (see particularly Nature, May 23, 1936, p. 855), a

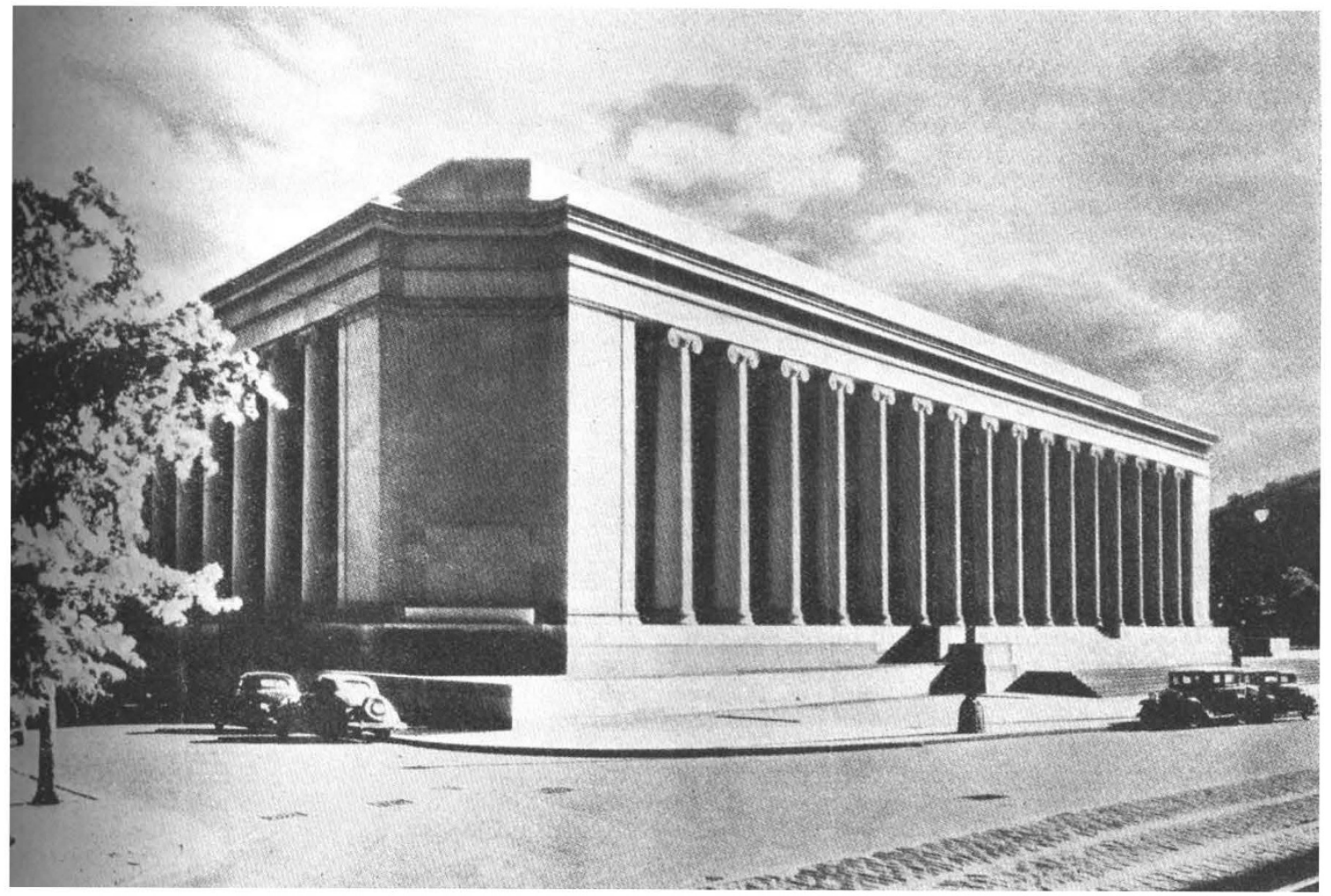

Fig. 1.

New blilding of Mellon Institcte, Pittsburgh, Pa.

Sir Frederick Banting and Dr. W. W. G. Maclachlan contributed.

The new Institute is the gift of the late Richard R. Mellon and his brother Andrew W. Mellon, formerly Secretary of the U.S.A. Treasury. Its origin is to be traced to Prof. Robert Kennedy Duncan's scheme of industrial fellowships, under which industrialists cooperate in the prosecution of specific researches. This scheme was first put into operation in 1907 in the University of Kansas and transferred to Pittsburgh in 1911. The Institute under its present name was founded in 1913 by the Mellon Brothers, who authorized Duncan to design a special building with adequate laboratory facilities. Duncan died prematurely in 1914 and the original building was dedicated in the following year, with Dr. Raymond F. Bacon as its first director. He was succeeded in 1921 by the present director, Dr. Edward R. Weidlein. summary of the present position and a brief description of the new building will suffice to commemorate the official opening of the largest building in the world dedicated to scientific research. The money appropriated by donors in support of industrial fellowships has amounted in the past twentysix years to $11,478,406$ dollars. In the financial year ending March 1, 1937, appropriations by donors were 816,315 dollars, and 69 fellowships have been in operation, employing 185 scientific workers and engineers. The Institute's contributions to the literature of science include 19 books, 143 bulletins, 744 research reports, and 1,117 papers published in journals; and 669 U.S. patents have been granted. Since $1911,1,150$ fellowships have been established in 275 technological subjects, and 650 processes or products have been invented or developed. In ten instances, new industries have resulted. From 1911 until 1935, 
no less than 777 scientific workers, having completed the work of their fellowships, have entered the field of manufacture or teaching, and this forms not the least valuable contribution to the promotion of science and industry. In recent years, the Institute has greatly developed its work of a more purely scientific character or bearing on public health. Its investigations on smoke abatement, dental caries, and anti-pneumococcic serum are examples.

With a view to simplicity, beauty and inspiration, the new building was designed in the Greek style (Fig. 1) with a relatively low elevation, three storeys being below ground level. The building has a capacity of $\epsilon_{2} \frac{1}{2}$ million cutic feet. Its colonnades have a total of sixty-two columns, each shaft--a single block of stone-weighing approximately 60 tons, of which twelve are on the south frontage, sixteen on the east and west and eighteen on the north. At the corners are impressive piers. Models were found in the small temple of Nike Apteros on the Acropolis and in the temple at Sardis in Asia Minor. On three sides a flight of steps leads up to the building. The fifth to eighth floors are devoted entirely to laboratories, most of the space being occupied by the two types of laboratory adopted by the Institute as standard. Doors connecting the laboratories are of aluminium adorned with alchemical symbols.

In accepting in 1935 the Chemical Industry Medal of the Society of Chemical Industry, Dr. Weidlein, the director, said that his task at the Institute had been to assist in infusing science into technology, particularly the chemical industry. This task had two aspects - to convince manufacturing organizations of the functions of scientific research and research management in industry, and to encourage in the public a greater appreciation of the value of science. Thanks to the work of the industrial fellows, the Institute formed a strong link between the world of science and the industries. His concluding words were :

"What about the future? I believe that all of us at the Institute will have much greater encouragement and opportunities and that we shall be able to do many more useful things when we have the advantage of working in our new building with its splendid facilities for research in pure as well as applied science."

\section{Kew's Contribution to Empire Botany}

$\mathrm{V}^{1}$ ISITORS to the Royal Botanic Gardens, Kew, who usually see only the Gardens and Muscums, can have little idea of the great role that the Herbarium near the Main Gate has played in the botanical service of the Empire. Since the Herbarium was founded in 1852, members of the staff have, indepen. dently and collectively, and in association with other botanists, accomplished a vast arnount of floristic work. In order to show the extent of this to the numerous visitors, particularly from overseas, who will no doubt visit the Gardens during the Coronation period, a special exhibit has been arranged in No. 3 Museum. In a large glass case there has been placed a selection of works prepared either wholly by, or with the assistance of, the scientific staff of the Herbarium and Museums.

The general books shown include the classical work of G. Bentham and J. D. Hooker, the "Genera Plantarum", 1862-83, which has been and is still used by botanists in all parts of the world. Next in order is the "Index Kewensis", a work of universal importance compiled at the expense of Charles Darwin, under the direction of Sir J. D. Hooker, by the late B. Daydon Jackson, and continued by various members of the staff. This gives references to the original descriptions of all known species of flowering plants. Alongside is the great index of plant illustrations, the "Index Londinensis", edited by the late $O$. Stapf. Besides these are the "Hortus Kewensis" of W. Aiton, 1789, which records the species of plants in cultivation at Kew when still a 'royal garden'; the Botanical Magazine, the oldest of botanical periodicals, commenced in 1787, and still prepared at Kew, but since 1922 the property of the Royal Horticultural Society; the Kew Bulletin, which this year attains its golden jubilee, having been started in 1887; and Hooker's "Icones Plantarum", which last year attained its centenary, and which provides a medium for the illustration of plants of exceptional botanical interest.

The botany of the British Isles is represented by Hooker's "Students' Flora" (1870) and by the "British Flora" of G. Bentham (ed. 1, 1858).

The vegetation of much of China and Tibet is recorded in Forbes and Hemsley's "Index Floræ Sinensis" (1886-1905), Bentham's "Flora Hongkongensis" (1861), and Dunn and Tutcher's "Flora of Hong Kong" (1912).

India has been well catered for by the "Flora of British India", by J. D. Hooker and others (1872-97), and the "Flora of Bombay", by T. Cook (1901-08), the "Flora Simlensis", by Collett and Hemsley (1962), the "Flora of the Upper Gangetic Plain", by J. F. Duthie (1903-29); "Bengal Plants" by D. Prain (1903) ; and the "Flora of Madras", by J. S. Gamble, completed by C. E. C. Fischer (1915-36). The forestry of India is dealt with in "Indian Trees", by D. Brandis (1907), and the "Forest Flora of the Andaman Islands", by C. E. Parkinson (1923).

The "Flora of the Malay Peninsula" (1922-25) was a heary undertaking by ono botanist, H. N. Ridley ; and the "Enumeration of Siamese Plants" (1925- ) by the late W. G. Craib, is being continued.

The continent of Australia was early provided for by G. Bentham's fundamental work, the "Flora Australiensis" (1863-78), and J. D. Hooker's "F]ora of Tasmania" (1860), whilst the "New Zealand Flora" (1864-77), by J. D. Hooker, and the "Illustrations of the New Zealand Flora" (1914) by Cheeseman, assisted by W. B. Hemsley, have done much for the botany of that Dominion. J. D. Hooker's "Flora Antarctica" (1847) is a classical work for that region.

Africa has always taken a first place in the activities of the Kew Herbarium, and several works of considerable magnitude have been issued dealing with 